\title{
Antibacterial Activities of Selected Samples of Honey in South-Western Nigeria against Bacteria in Wound Infections
}

\author{
Morenike O Adeoye-Isijola1, Olufunmiso 0 Olajuyigbe ${ }^{1,2}$, \\ Babasola A Osopale ${ }^{1}$, Anthony Nwankwo ${ }^{1}$, Otunola Adedayo²
}

\author{
${ }^{1}$ Department of Microbiology, Babcock University, Ilisan Remo, Ogun State, Nigeria \\ ${ }^{2}$ Department of Microbiology, Kwara State University, Ilorin, Kwara State, Nigeria
}

\begin{abstract}
The global challenges resulting from the emergence of numerous resistant pathogenic bacteria have led to a search for alternative therapy ethnomedically. As a result, honey is increasingly valued for its antibacterial activity. In this study, the antibacterial activity of different honey samples was assessed in vitro using agar dilution at different concentration of 5\%, 10\%, 20\%, 30\%, 40\%, 50\%, 75\% and 100\% (v/v) dilution. The antibacterial activity was also determined by spectrophotometric assay at $620 \mathrm{~nm}$. The result showed that KG honey sample inhibited the different bacterial isolates at a concentration of 5\% and LB honey sample inhibited the isolates at $20 \%$ while other honey samples inhibited the bacterial isolates at concentrations ranging between $10 \%$ and $30 \%$ (v/v) dilution of each honey samples. Thus, the minimum inhibitory concentrations ranged between a concentration of 5\% and 30\% (v/v) dilution even though antibacterial activities concentration ranged from $5 \%-100 \%(\mathrm{v} / \mathrm{v})$. Ps. aeruginosa ATCC 15442 was considered the most susceptible of all the test isolates. The increases in the absorbances showed that the bacterial populations in each of the honey samples were reduced as the exposure time increases. The study shows that honey being sold in Nigeria may be used as a therapeutic agent to treat infections as they may be an excellent alternative to curtail the further spreading of multi-drug-resistant microorganisms in Nigeria.
\end{abstract}

Running Title: Antibacterial activities of honey against bacteria

Keywords: Antibacterial, Honey, Multidrug Resistance, Wound Infections

\section{INTRODUCTION}

Honey produced by Apis mellifera is one of the oldest traditional medicines considered important in the treatment of several human ailments (Mondo et al., 2004). The ancient Greeks believed that consuming honey could result in living longer (Kwakman et al., 2002). While many pathogenic organisms have developed resistance to many antibiotics (Patton et al., 2006) and multidrug resistance is on the increase, efforts are being intensified to develop antimicrobial agents from natural sources for better therapeutic effects (Gills et al., 1992). Consequently, despite the fact that researchers have focused on the bactericidal potential of honey against many pathogenic aerobic and anaerobic, Gram-negative and Gram-positive bacteria (Haffejee et al., 1985; Hannan et al., 2004), Basson et al. (1994) and Lusby et al. (2005) indicated that natural unheated honey has some broad-spectrum antibacterial activity against pathogenic, oral and food spoilage bacteria.

\begin{abstract}
Although the chemical component of honey is dependent on the type of honey, geographical location, season, flower source from which the final product is derived and production methods ((Molan and Cooper, 2000; Nisbet et al., 2010), honey contains enzymatic and non-enzymatic antioxidants (Bogdnov, 1989), numerous types of sugar, acids, vitamins, protein and minerals (Al-Waili et al., 2004) as well as alkaloids, antaquinone, glycosides, cardiac glycosides, flavonoids and reducing compounds (Chute et al., 2010). High sugar concentration, low $\mathrm{pH}$, hydrogen peroxide generation, proteinaceous compounds or other unidentified components present in the honey may provide antimicrobial activity (Mundo et al., 2004). Besides its antimicrobial properties, honey can clear infections in a number of ways in vivo, boost the immune system, act as antiinflammatory and antioxidant agents and stimulate cell growth (Al-jabri et al., 2005). While raw honey contains copious amounts of flavonoids and other polyphenols exhibiting different biological activities and act as antioxidants (Blassa et al., 2006;
\end{abstract}

This article is published under the terms of the Creative Commons Attribution License 4.0

Author(s) retain the copyright of this article. Publication rights with Alkhaer Publications.

Published at: http://www.ijsciences.com/pub/issue/2017-09/

DOI: 10.18483/ijSci.1423; Online ISSN: 2305-3925; Print ISSN: 2410-4477 
Pyrzyńska and Biesaga, 2009), methyl syringate and methylglyoxal contribute to the non-peroxide activities of honey (Marvic, 2008; Adams et al., 2008).

Since honey has been used from ancient times as a method of accelerating wound healing (Van der berg et al., 2008), its possibility to heal wound has constantly been demonstrated (Molan, 2006; Simon et al., 2008). The antibacterial properties of honey increase the growth of new tissue to heal the wound (Lusby et al., 2002). When applied topically, it rapidly clears wound infection to facilitate healing of deep surgical wounds with infection (Ahmed et al., 2003). Its application can promote the healing of peptic ulcers and gastritis (Molan et al., 2001) and methicillin-resistant $S$. aureus infected wounds (Natarajan et al., 2003). In cognizance of its therapeutic potential, the antimicrobial activities of diluted honey from different countries have been reported (Voidarou et al., 2011; Moussa et al., 2012). In Nigeria, there is a need to validate the therapeutic potentials and the antibacterial activities of different honey samples commonly sold for consumption. The aim of this study, therefore, was to investigate the antibacterial activities of five different honey samples against bacteria in wound infections.

\section{MATERIALS AND METHODS \\ Honey Samples}

Five different honey samples locally produced honey from apiary were bought from different pharmaceutical outlets in the Southwest part of Nigeria. The honey samples were stored at $23-25^{\circ} \mathrm{C}$ in the dark. For antibacterial assays, each of the honey samples was used undiluted and at 5\%, 10\%, $20 \%, 30 \%, 40 \%, 50 \%$ and $75 \%$ v/v dilution by weighing a required amount of each of the honey and diluting to a final volume of $100 \mathrm{ml}$ with sterile deionized distilled water (Cooper et al., 2002a). Incubation was carried out in the dark because both hydrogen peroxide and glucose oxidase are light sensitive (White et al., 1963).

\section{Test microorganisms}

The test organisms including Pseudomonas aeruginosa ATCC 15442, Shigella flexineri KZN, Enterococcus faecalis KZN, Escherichia coli ATCC 25922, Serratia mercescens ATCC 9986, Klebsiella pneumoniae ATCC4352, Proteus vulgaris ATCC 6830, Enterococcus faecalis ATCC 29212, Enterococcus cloacae ATCC 13047 and Shigella sonnei ATCC 29930 were obtained from the Department of Biochemistry and Microbiology, University of Fort Hare, Alice, South Africa. Colonies from fresh overnight growth cultures of the different bacterial strains were suspended in $3-4 \mathrm{ml}$ sterile nutrient broth and incubated for $2-3 \mathrm{~h}$ at $37^{\circ} \mathrm{C}$. These isolates were diluted with distilled water and adjusted to $0.5 \mathrm{McF}$ arland's standard yielding approximately $1.0 \times 10^{6} \mathrm{CFU} / \mathrm{ml}$ before being used in this study.

\section{Antibacterial testing by agar dilution method}

The antibacterial activity of the different honey samples was carried out by agar dilution and spectrophotmetric assays (Patton et al., 2006; Tan et al., 2009). For the agar dilution assay, double strength Mueller Hinton Agar (MHA) medium was prepared and incorporated with the different honey samples at concentrations (v/v Honey $+\mathrm{MAH})$ of $5 \%, 10 \%, 20 \%, 30 \%, 40 \%, 50 \%$ and $75 \%$. Since honey is a very viscous liquid, it was kept at $50^{\circ} \mathrm{C}$ before mixing with the agar to achieve uniform homogenization. On mixing the honey with the Mueller Hinton agar maintained at $50^{\circ} \mathrm{C}$, the mixture was vigorously vortexed and dispensed into sterile petri dishes. After being allowed to solidify, each of the test organisms was streaked on the different concentrations of the different honey samples before being incubated at $37^{\circ} \mathrm{C}$ for $24 \mathrm{~h}$ and observed for growth. The experiment was performed in duplicate to ensure reproducibility of the results. Three agar plates sere set up as controls. One agar plate was inoculated with all test strains to confirm their viability. Second control plate contained medium only and the third plate contained different honey samples to check for the sterility of the medium and the honey. The minimum inhibitory concentration (MIC) was recorded as the lowest concentration of honey at which no visible bacterial growths were observed.

\section{Spectrophotometric testing}

The sample was prepared by weighing $30 \%$, mix well and poured into 10 test tubes, after which diluted 100 $\mu \mathrm{l}$ of the test organisms were introduced into the 10 test tubes. Spectrophotometric reading was taken at 0 $\mathrm{h}, 1 \mathrm{~h}, 2 \mathrm{~h}, 3 \mathrm{~h}, 4 \mathrm{~h}, 5 \mathrm{~h}, 6 \mathrm{~h}$ at $625 \mathrm{~nm}$. These are aimed at determining the level of turbidity after hours of inoculation.

\section{RESULT}

In this study, the different honey samples exhibited a varied degree of inhibitory effects against the different bacterial isolates. The minimum inhibitory concentrations of the honey samples varied from each other against the bacterial isolates. While KG honey sample inhibited the different bacterial isolates at a concentration of 5\% and LB honey sample inhibited these isolates at $20 \%$, other honey samples inhibited the bacterial isolates at concentrations ranging between $10 \%$ and $30 \%(\mathrm{v} / \mathrm{v})$ dilution of each honey samples. While six of the isolates were inhibited by 
$20 \%$ dilution and four of the isolates were inhibited at $30 \%$ of the UB honey dilution and this antibacterial activity was a reverse in NF honey samples, eight of the isolates were inhibited by $10 \%$ and two isolates were inhibited by the $20 \%$ of the DB honey samples as shown in Table 1. No microbial growths were observed on the agar plates containing honey samples used as sterility test for each of the honey samples. While KG honey was the most effective honey inhibiting bacterial isolates at 5\%, Ps. aeruginosa
ATCC 15442 was considered the most susceptible of all the test isolates. From Figures 1-5, the spectrophotometric reading of the antibacterial activities of the different honey samples showed that there were increases in the reading of the absorbances at $625 \mathrm{~nm}$ over a period of $6 \mathrm{~h}$. The increases in the absorbances showed that the bacterial populations in each of the honey samples were reduced to allow more penetration of light as the exposure time increases.

TABLE 1: Antibacterial activity of five different pure natural undiluted honey (v/v)

\begin{tabular}{llllll}
\hline & \multicolumn{4}{l}{ Minimum inhibitory concentrations of different hone samples (v/v) } \\
\hline Organisms used & KG honey & UB honey & LB honey & NF honey & DB honey \\
\hline E. claocae KZN & $5 \%$ & $20 \%$ & $20 \%$ & $30 \%$ & $10 \%$ \\
P. vulgaris ATCC 6830 & $5 \%$ & $30 \%$ & $20 \%$ & $10 \%$ & $10 \%$ \\
E. faecalis KZN & $5 \%$ & $20 \%$ & $20 \%$ & $30 \%$ & $20 \%$ \\
E. coli ATCC 25922 & $5 \%$ & $30 \%$ & $20 \%$ & $30 \%$ & $10 \%$ \\
S. flexineri KZN & $5 \%$ & $20 \%$ & $20 \%$ & $30 \%$ & $10 \%$ \\
Ps. aeruginosa ATCC 15442 & $5 \%$ & $20 \%$ & $20 \%$ & $10 \%$ & $10 \%$ \\
S. sonnei ATCC 29930 & $5 \%$ & $30 \%$ & $20 \%$ & $10 \%$ & $10 \%$ \\
K. pneumoniae ATCC 10031 & $5 \%$ & $30 \%$ & $20 \%$ & $20 \%$ & $20 \%$ \\
S. mercescens ATCC 9986 & $5 \%$ & $20 \%$ & $20 \%$ & $30 \%$ & $10 \%$ \\
Ps. aeruginosa ATCC 19582 & $5 \%$ & $20 \%$ & $20 \%$ & $30 \%$ & $10 \%$ \\
\hline
\end{tabular}

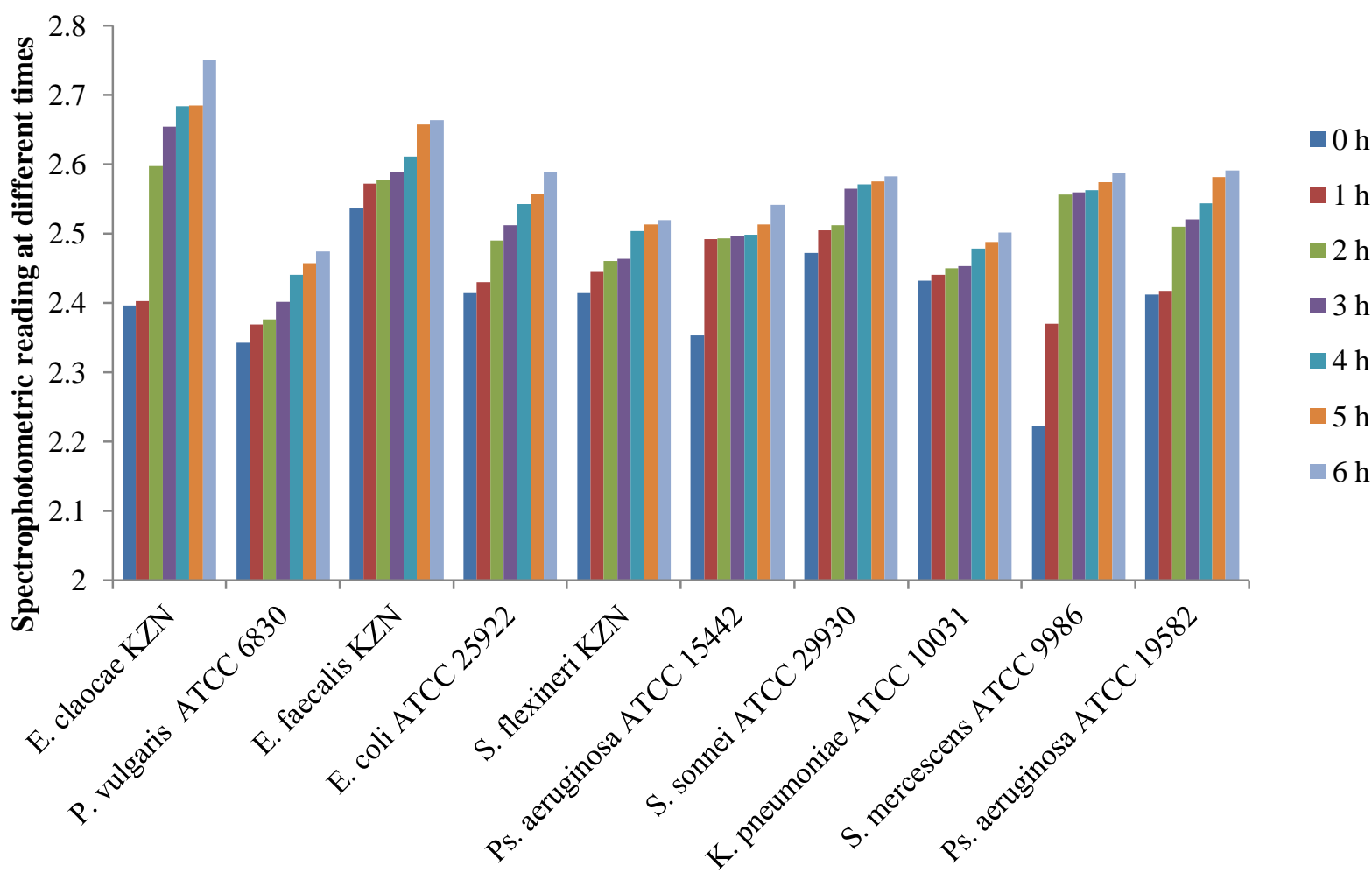

Bacterial susceptibility to KG honey at different time interval

Figure 1: Spectrophotometric reading (kinetics) of bacterial susceptibility in KG honey $30 \%$ (v/v) 


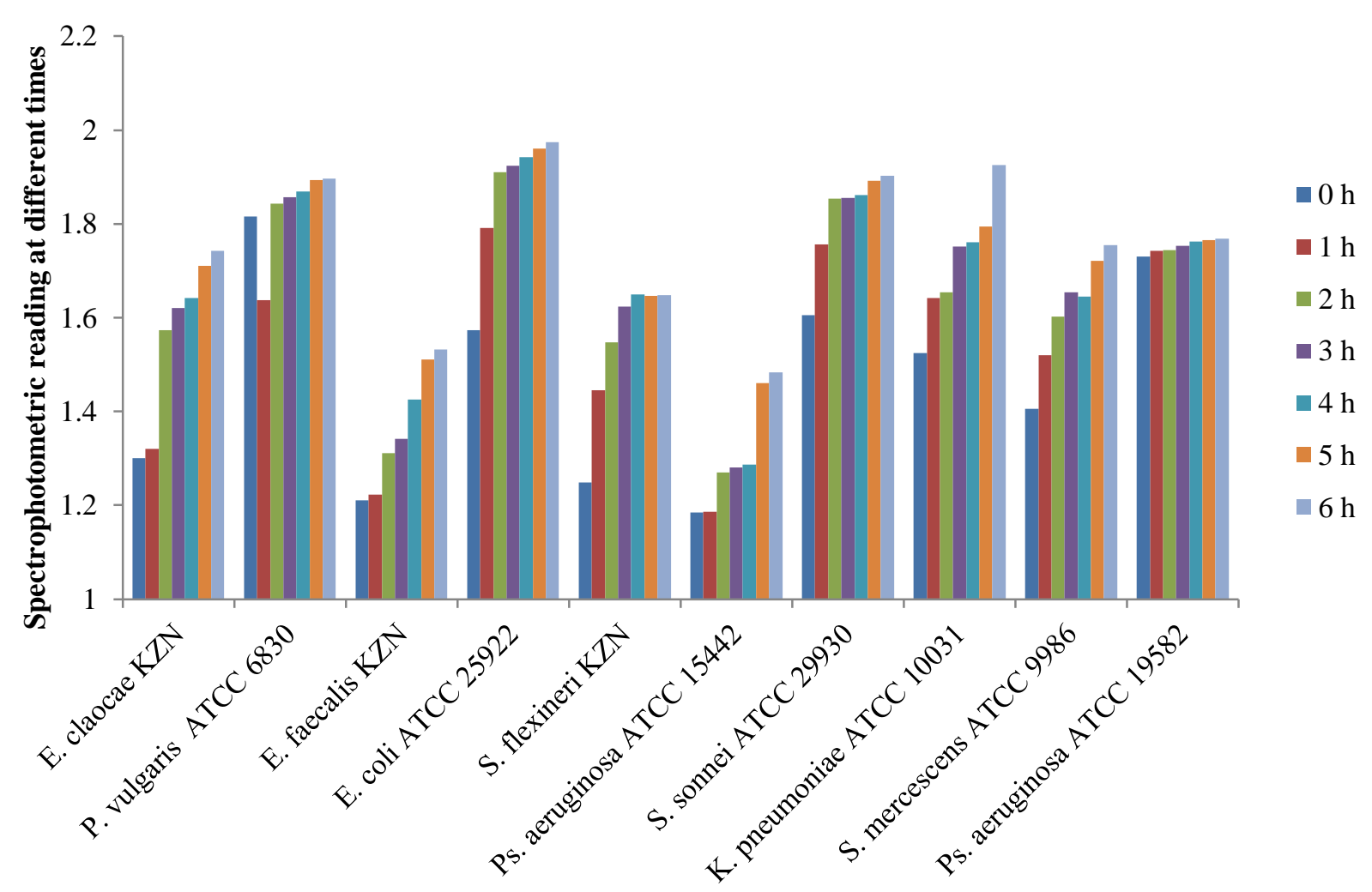

Bacterial susceptibility to UB honey at different time interval

Figure 2: Spectrophotometric reading (kinetics) of bacterial susceptibility to UB honey 30\% (v/v)

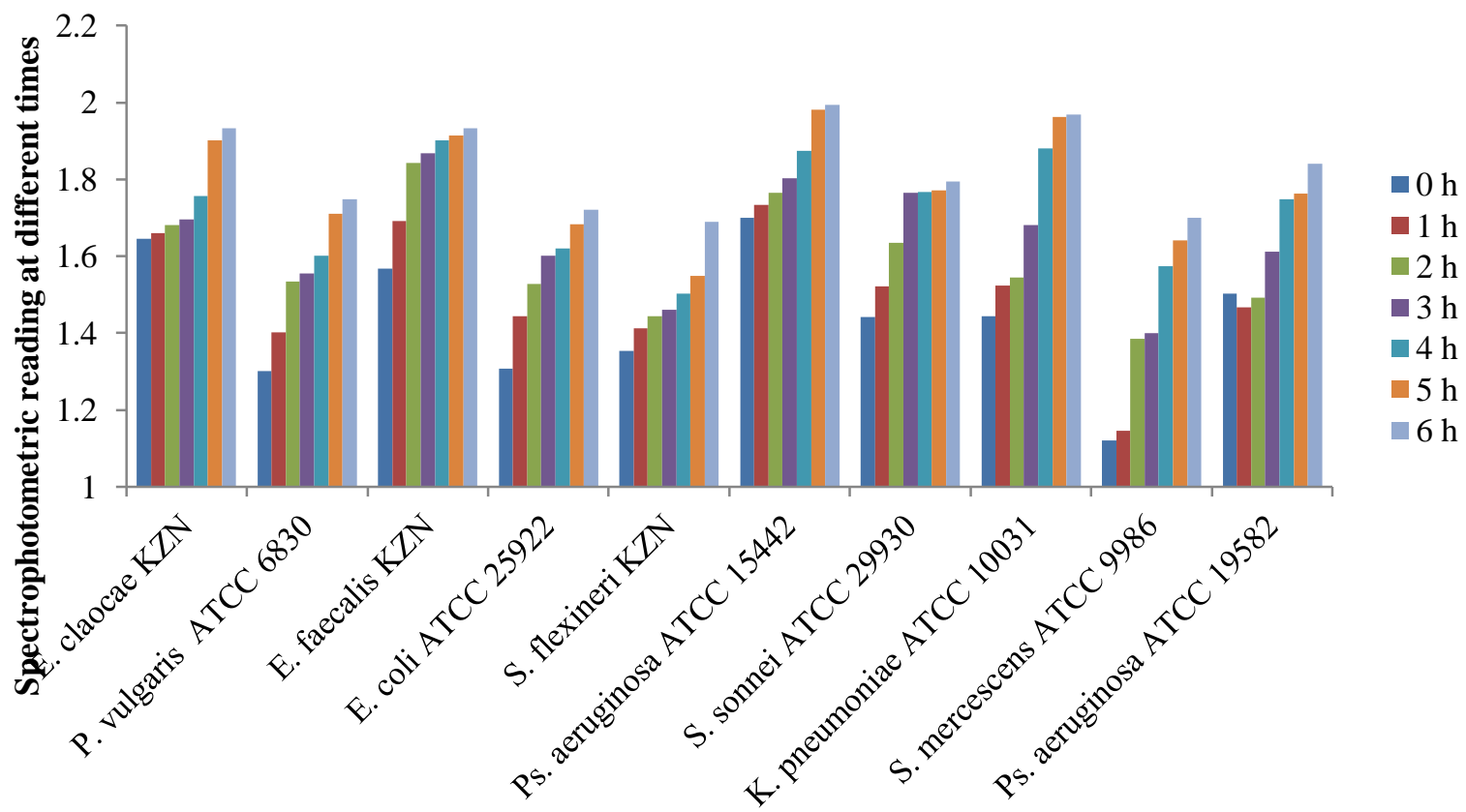

Bacterial susceptibility to LB honey at different time interval

Figure 3: Spectrophotometric reading (kinetics) of bacterial susceptibility in LB honey 30\% (v/v) 


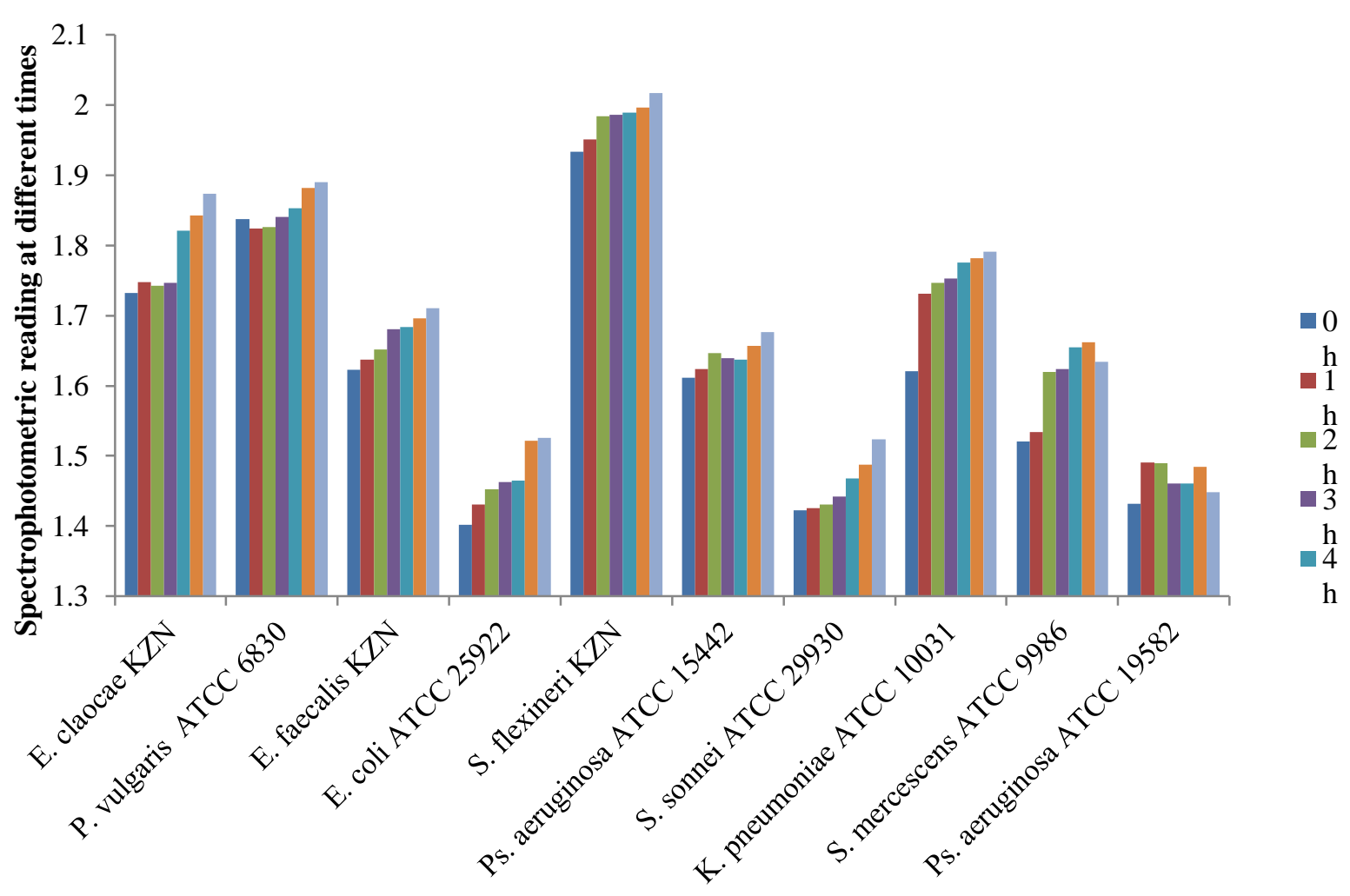

Bacterial susceptibility to NF honey at different time interval

Figure 4: Spectrophotometric reading (kinetics) of bacterial susceptibility in LB honey 30\% (v/v)

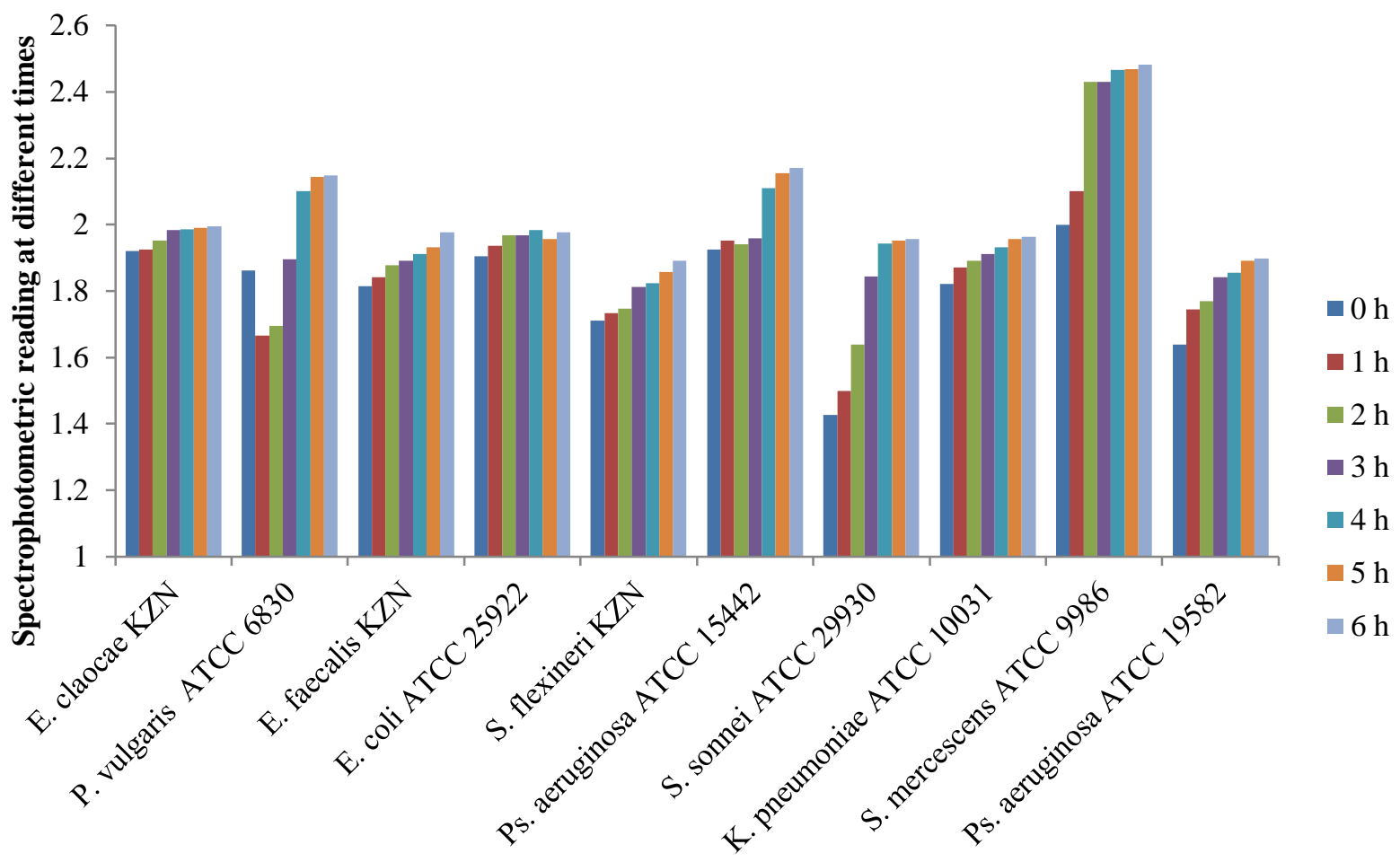

Bacterial susceptibility to DB honey at different time interval

Figure 5: Spectrophotometric reading (kinetics) of bacterial susceptibility in LB honey 30\% (v/v) 


\section{DISCUSSION}

The control of infectious diseases due to antimicrobial resistance is a serious challenge to be addressed (WHO, 2010). In the recent time, the emergence of numerous resistant pathogenic bacterial strains to a wide range of formerly efficient antibiotics has constituted a serious threat to public health (Raymond et al., 2011) while this incidence has paved way to the occurrence of infections that are only treated by a limited number of antimicrobial agents (Roula et al., 2010). This global challenge, calling for the development of new antibiotics sufficient for the treatment of chronic infections (Choffnes et al., 2010), has led a great population of the world to rely on traditional medicines as primary health care, as an alternative and complementary medicines (WHO, 2008) because they are natural, less expensive, non-toxic and has no adverse effects on the healing process of tissues (Dunford et al., 2000; Lusby et al., 2002; Hamzaoglu et al., 2000). Consequently, efforts have been unleashed by researchers to unravel the unknown benefits of the inestimable attributes of honey and its applications (Irish et al., 2008; Cursons, 2010; Kumari et al., 2010; Zaid et al., 2010).

From this study, the absence of microbial growths on agar plates used as sterility control test may be due to the inhibitory effects of the chemical components of the different honey samples (Souza et al., 2007; Teixeira et al., 2008). If bacteria had been detected in the control samples, the presence of isolates may have indicated contamination from a secondary source. However, the antibacterial activities of the different honey samples showed that the minimum inhibitory concentrations ranged between a concentration of $5 \%$ and $30 \%(\mathrm{v} / \mathrm{v})$ dilution even though antibacterial activities concentration ranged from 5\% - 100\% (v/v). While Nzeako and Hamdi (2000) indicated that honey had no activity at $40 \%$ (v/v) dilution, Chanchao et al. (2006) indicated that honey provides the same inhibition ability at $25 \%$ and $50 \%(\mathrm{v} / \mathrm{v})$ dilution but not at a dilution of $75 \%$ (v/v). Lusby et al., (2005) reported that honey other than commercially available antibacterial honeys like manuka (Leptopsermum scoparium) honey can have equivalent antibacterial activity on certain clinical isolates. Although the antibacterial activity of different types of honey can vary by a factor up to 100 (Willix et al., 1992), the great variety of antibacterial activity of honey may be attributed to differences in the botanical and geographical origin, and consequently in the chemical composition (Akkol et al., 2007).

In previous studies, the antimicrobial activities of honey have been reported. Zumla and Lulat (1989) reported that honey is a very good inhibitor to E. coli, Salmonella and Shigella. French et al. (2005) reported the effectiveness of manuka honey against pathogenic bacteria such as $S$. aureus and Helicobacter pylori. Wilkinson (2005) investigated the susceptibility of E. coli and Ps. aeruginosa to the activity of 13 honey samples. Tan et al., (2009) reported that honey samples, in their study, showed activity against E. coli, $S$. aureus, B. Subtilis and Ps. aeruginosa. These reports are in agreement with the results of the present study. The antibacterial effect of the different honey that was used in this study showed a remarkable effect through the rate at which they inhibited the test bacterial isolates used. The bacterial growths were diversely inhibited at concentrations of $5 \%, 10 \%, 20 \%, 30 \%, 40 \%$ and $50 \%(\mathrm{v} / \mathrm{v})$ dilution of the honey samples. Although the mechanism of antibacterial action of honey is most likely a combination of a number of different factors, the antibacterial activity in most honey samples is due to the enzymatic production of hydrogen peroxide in addition to unidentified phytochemical components (Cooper et al., 2002b). While its dilution enhances hydrogen peroxide mediated antibacterial activity (Melissa et al., 2004), honey has antioxidant properties and increases cytokine release which may explain its antimicrobial effects (Gheldof et al., 2002; Schramm et al., 2003; Tonks et al., 2003). Since hydrogen peroxide is a major contributor to the antimicrobial activity of honey, the different concentrations of this compound in the different honeys could have resulted in their varying antimicrobial effect recorded in this study.

In conclusion, this study confirms that honey possesses antimicrobial activity and holds great promise as antimicrobial agent against pathogenic microorganisms. It may be used as a therapeutic agent and an effective herbal medicine to treat infections as they may be an excellent alternative to curtail the further spreading of multi-drug-resistant microorganisms in Nigeria.

\section{REFERENCES}

1. Adams, C.J.; Boult, C.H.; Deadman, B.J.; Farr, J.M.; Grainger, M.N.C.; Manley-Harris, M.; et al. Isolation by HPLC and characterisation of the bioactive fraction of New Zealand manuka (Leptospermum scoparium) honey. Carbohyd. Res., p. 651-659, v. 343, 2008.

2. Ahmed, A.K.; Hoekstra, M.J.; Hage, J.; Karim, R.B. Honeymedicated dressing: transformation of an ancient remedy into modern therapy. Ann. Plastic Surg., p. 143-148, v. 50, 2003.

3. Akkol, E.; Yesxilada, E.; Güvenc, A. Valuation of antiinflammatory and antinociceptive activities of Erica species native to Turkey. J. Ethnopharmacol., p. 251-257. v. 116 , 2007.

4. Al-Jabri A.A. Honey, milk and antibiotics. Afr. J. Biotechnol., p. 1580-7, v. 4, 2005.

5. Al-Waili, N.S.; Akmal, M.; Al-Waili, F.S.; Saloom, K.Y.; Ali A. The antimicrobial potential of honey from United Arab 
Emirates on some microbial isolates. Med. Sci. Monitor., p. 433-438, v. 11, 2005

6. Basson, N.J.; duToit, I.J.; Grobler, S.R. Antibacterial action of honey on oral streptococci. J. Dental Ass. South Afr., p. 339-341, v. 49, 1994.

7. Blasa, M.; Candiracci, M.; Accorsi, A.; Piacentini, M.P.; Albertini, M.C.; Piatti, E. Raw Millefiori honey is packed full of antioxidants. Food Chem., p. 217-222, v. 97, 2006.

8. Bogdnov, S. Determination of pinocembrin I honey using HPLC. J. Agri. Res., p. 55-57, v. 23(1), 1989.

9. Chanchao, C.; Sintara, K.; Wongsiri, S. Comparison of antibiotic and organoleptic properties of honey from various plant sources in Thailand. J. Apicult. Sci., p. 59-63, v. 50(2), 2006.

10. Choffnes, E.R.; Relman, D.A.; Mack A. "Antibiotic Resistance: Implications for Global Health and Novel Intervention Strategies," Workshop Summary, National Academies Sciences, Washington DC., 2010. http://www.ncbi.nlm.nih.gov/books/NBK45639/pdf/nap1292 5.pdf

11. Chute, R.K.; Deogade, N.G.; Kawale M. Antimicrobial activity of Indian honey against clinical isolates, Asiatic Journal of Biotechnology Resources. Asiatic J. Biotechnol. Res., p. 35-38, v. 01, 2010.

12. Cooper, R.A.; Molan, P.C.; Harding, K.G. The sensitivity to honey of gram positive cocci of clinical significance isolated from wounds. J. Appl. Microbiol., p. 857-863, v. 93, 2002a.

13. Cooper, R.A.; Halas, E.; Molan, P.C. The efficacy of honey in inhibiting strains of Pseudomonas aeruginosa from infected burns. J. Burn Care and Rehab., p. 366-70, v. 23(6), $2002 b$

14. Cursons, R.T. The post-antibiotic effect of manuka honey on gastrointestinal pathogens. Int. J. Antimicrob. Agents., p. 467-482, v. 36(5), 2010.

15. Dunford, C.; Cooper, R.A.; Molan, P., et al. The use of honey in wound management. Nurs. Standard., p. 63-8, v. 15, 2000.

16. French, V.M.; Cooper, R.A.; Molan P.C. The antibacterial activity of honey against coagulase-negative Staphylococci. J. Antimicrob. Chemother., p. 228-231, v. 56, 2005.

17. Gheldof, N.; Wang, X.H.; Engeseth, N.J. Identification and quantification of antioxidant components of honeys from various floral sources. J. Agric. Food Chem., p. 5870-5877, v. 50(21), 2002

18. Gills, L.S. Ethno-medical uses of plants in Nigeria. Ilupeju Press Ltd. Pp 165-250, 1992.

19. Haffejee, I.E.; Moosa, A. Honey in the treatment of infantile gastroenteritis. British Med. J., p. 1866-1867, v. 290, 1985.

20. Hamzaoglu, I.; Saribeyoglu, K.; Durak, H.; et al. Protective covering of surgical wounds with honey impedes tumor implantation. Arch. Surg., p. 1414-1417, v. 135(12), 2000.

21. Hannan, A.; Barkaat, M.; Saleem, S.; Usman, M.; Gilani, W.A. Manuka honey and its antimicrobial potential against multidrug resistant strains of Typhoidal salmonellae, Ph.D. thesis, Department of Microbiology, University of Health Science, Lahore, Pakistan, 2004.

22. Irish, J.; Carter, D.E.; Blair, S.E.; Heard, T.A. Antimicrobial activity of honey from the Australian stingless bee Trigona carbonaria. J. Antimicrob. Agents., p. 89-98, v. 32(1), 2008. Kumari, S.; Harjai, K.; Chhibber, S. Topical Treatment of Klebsiella pneumoniae B5055 induced burn wound infection in mice using natural products. J. Infect. Dev. Countries., v. 4(6), p. 367-377, 2010.

23. Kwakman, P.H.; Velde, A.A.; de Boer, L.; Speijer, D.; Vandenbroucke-Grauls, C.M.; Zaat, S.A. How honey kills bacteria. FASEB J., p. 2576-82, v. 24(7), 2010.

24. Lusby, P.E.; Coombes, A.; Wilkinson, J.M. Honey: a potent agent for wound healing? J. Wound, Ostomy and Cont, Nurs., p. 295-300, v. 29(6), 2002

25. Lusby, P.E.; Coombes, A.L.; Wilkinson, J.M. Bactericidal activity of different honeys against pathogenic bacteria. Arc. Med. Res., p. 464-467, v. 36(5), 2005.
26. Marvic, E.; Wittmann, S.; Barth, G.; Henle T. Identification and quantification of methylglyoxal as the dominant antibacterial constituent of manuka (Leptospermum scoparium) honeys from New Zealand. Mol. Nutr. Foods Res., p. 483-489, v. 52(4), 2008

27. Melissa, A.M.; Olga, I.P.Z.; Randy, W.W. Growth inhibition of food borne pathogens and food spoilage organisms by select raw honeys. Int. J. Food Microbiol., p. 1-8, v. 97, 2004.

28. Molan PC, Cooper RA. Honey and sugar as a dressing for wounds and ulcers. Trop Doct., p. 249-250, v. 30, 2000.

29. Molan, P. Potential of honey in the treatment of wounds and burns. Am. J. Clin. Dermatol., p.13-19, v. 2(1), 2001.

30. Molan, P.C. The evidence supporting the use of honey as a wound dressing. Int. J. Low Extremity Wounds., p. 40-54, v. 5(1), 2006

31. Moussa, A.; Djebli, N.; Meslem, A.; Aissat, S. Antibacterial activity of various honey types of Algeria against Pathogenic Gram-Negative Bacilli: Escherichia coli and Pseudomonas aeruginosa. Asian Pac. J. Trop. Dis., p. 211-214, 2012.

32. Mundo, M.A.; Padilla-Zakour, O.I.; Worobo, R.W. Growth inhibition of foodborne pathogens and food spoilage organisms by select raw honeys. International Journal of Food Microbiology. p.1-8, v. 97, 2004.

33. Natarajan, S.; Williamson, D.; Grey, J., Harding, K.G.; Cooper, R.A. Healing of an MRSA-colonized hydroxyureainduced leg ulcer with honey. J. Dermatol. Treatment., p. 3336, v. 12(1), 2001.

34. Nisbet H.O., et al. Effects of three types of honey on cutaneous wound healing. Wounds., p. 275-283, v. 22(11), 2010.

35. Nzeako, B.C.; Hamdi, J. Antimicrobial potential of honey on some microbial isolates. J. Med. Sci., p. 75-79, v. 2, 2000.

36. Patton, T.; Barrett, J.; Brennan, J.; Moran, N. Use of a spectrophotometric bioassay for determination of microbial sensitivity to manuka honey. J. Microbiol. Methods., p. 8495 , v. 64(1), 2006.

37. Pyrzyńska, K.; Biesaga, M. Analysis of phenolic acids and flavonoids in honey. Trends Analyt. Chem., p. 893-902, v. 28, 2009.

38. Raymond, M.S.; Rosalie, N.A.N.; Paul, L.K.; Martin, K.M.; Alambert, T.T.; Guy, N.S.S.; et al. Antibacterial and dermal toxicological profiles of ethyl acetate extract from Crassocephalum bauchiense (Hutch.) Milne-Redh (Asteraceae). BMC Compl. Alt. Med., p. 43-9, v. 11, 2011

39. Roula A.M., Elias A., Elias B., Ziad D. Antibacterial activity of the extracts obtained from Rosmarinus officinalis, Origanum majorana and Trigonella foenumgraecum on highly drug resistant Gram negative bacilli. J. Bot., p. 1-8, Article ID: 464087, 2010

40. Schramm, D.D.; Karim, M.; Schrader, H.R.; Holt, R.R.; Cardetti, M.; Keen, C.L. Honey with high levels of antioxidants can provide protection to healthy human subjects. J. Agric. Food Chem., p. 1732-1735, v. 51(6), 2003.

41. Simon, A.; Traynor, K.; Santos, K.; Blaser, G.; Bode, U.; Molan, P. Medical honey for wound care - still the 'Latest Resort'. Evidenc-Based Compl. Alt. Med., p. 165-173, v. 6(2), 2008

42. Souza, R.M.; de Souza, M.C.; Patitucci, M.L.; Silva, J.F. Evaluation of antioxidant and antimicrobial activities and characterization of bioactive components of two Brazilian propolis samples using a pKa-guided fractionation Zeitschrift fur Naturforsch C. p. 801- 807, v. 62(11-12), 2007.

43. Tan, H.Z.; Abdul Rahman, R.; Gan, S.H.; Halim, A.S.; Hassan, S.A.; et al. The antibacterial properties of Malaysian tualang honey against wound and enteric microorganisms in comparison to manuka honey. BMC Compl. Alt. Med., p. 34, v. $9,2009$.

44. Teixeira, E.W.; Message, D.; Negri, G.; Salatino, A.; Stringheta, P.C. Seasonal variation, chemical composition 
and antioxidant activity of Brazilian propolis samples. Evidence-Based Compl. Alt. Med., p. 307-315, v. 7(3), 2008.

45. Tonks, A.J.; Cooper, R.A.; Jones, K.P.; Blair, S.; Parton, J.; Tonks, A. Honey stimulates inflammatory cytokine production from monocytes. Cytokine., vp. 242-247, 21(5), 2003.

46. Van den Berg, A.J.; Van den Worm, E.; Van Ufford, H.C.; Halkes, S.B.; Hoekstra, M.J.; Beukelman, C.J. An in vitro examination of the antioxidant and anti-inflammatory properties of buckwheat honey. J. Wound Care., p. 172-178, v. 17(4), 2008

47. Voidarou, C.; Alexopoulos, A.; Plessas, S.; Karapanou, A.; Mantzourani, I.; Stavropoulou, E.; et al. Antibacterial activity of different honeys against pathogenic bacteria. Anaerobe., p. 375-379, v. 17(6), 2011.

48. White, J.W. Jr.; Subers, M.M.; Scheparts, A.I. The identification of inhibine, the antibacterial factor in honey as hydrogen peroxidase and its origin in a honey glucose oxidase system. Biochim Biophys Acta., p. 57-70, v. 73, 1963.
49. World Health Organisation (WHO) Traditional Medcines. Media Centre, No. 134, 2008.

50. World Health Organisation (WHO) ()- "Containing Antimicrobial Resistance: A Renewed Effort," Bulletin of the World Health Organization, p. 877-953, v. 88(12), 2010. http://www.who.int/bulletin/volumes/88/12/10-084236/en

51. Wilkinson, J.M. Antibacterial Activity of 13 Honeys against Escherichia coli and Pseudomonas aeruginosa. J. Med. Food., p. 100-103, v. 8, 2005.

52. Willix, D.J.; Molan, P.C.; Harfoot, C.J. A comparison of the sensitivity of wound infecting species of bacteria to the antibacterial activity of manuka honey and other honey. J. Appl. Microbiol., p. 388-94, v. 73, 1991.

53. Zaid, S.S.; Sulaiman, S.A.; Sirajudeen, K.N.M.; Ortman, N.H. The Effects of Tualang Honey on Female Reproductive Organs, Tibia Tone and Hormonal Profile in Ovariectomised Rats-Animal Model for Menopose. BMC Compl. Alt. Med. p. 82, v. 10, 2010.

54. Zumla, A.; Lulat, A. Honey--a remedy rediscovered. J. Roy. Soc. Med., p. 384-385, v. 82, 1989. 